\title{
Jurist-Diction
}

Volume 3 No. 6, November 2020

\section{Wewenang Hakim Menilai Sendiri Kerugian Negara Dalam Mengadili Tindak Pidana Korupsi}

\author{
Dimas Prasanto Kusuma \\ prasantokusuma@yahoo.com \\ Universitas Airlangga
}

\begin{abstract}
How to cite:
Dimas Prasanto Kusuma,

'Wewenang Hakim Menilai

Sendiri Kerugian Negara

Dalam Mengadili Tindak

Pidana Korupsi' (2020) Vol. 3

No. 6 Jurist-Diction

Histori artikel:

Submit 1 September 2020;

Diterima 22 September 2020;

Diterbitkan 1 November 2020

DOI:

10.20473/jd.v3i6.22961
\end{abstract}

\begin{abstract}
Abstrak
Kewenangan menilai dan menghitung kerugian negara berdasarkan Pasal 32 Undang-Undang Nomor 31 Tahun 1999 juncto UndangUndang Nomor 20 Tahun 2001 menimbulkan permasalahan dalam persidangan karena hanya instansi yang berwenang untuk menghitung kerugian negara, hal ini tentunya menimbulkan pertanyaan tentang apakah hakim sebagai wakil tuhan didunia untuk menegakan keadilan dapat menunjukan sisi kemerdekaan hakim dalam memutus perkara. Hakim dalam mengadili perkara tindak pidana korupsi memperoleh kewenangan menilai sendiri kerugian negara berdasarkan fakta persidangan sesuai dengan Pasal 6 surat edaran mahkamah agung Nomor 4 Tahun 2016. Tidak terikatnya hakim dengan hasil instansi yang berwenang terhadap hasil audit kerugian negara hal ini menujukan sisi kemerdekaan hakim berdasarkan Pasal 1 angka 1 Undang-Undang Nomor 48 Tahun 2009.

Kata Kunci: Hakim; Kerugian Negara; Tindak Pidana Korupsi.
\end{abstract}

\section{Pendahuluan}

Bentuk kejahatan korupsi di Indonesia mulai dari: Korupsi pengadaan barang dan jasa, mark up anggaran pembangunan, penyalahgunaan jabatan, gratifikasi, dan bahkan korupsi dana bantuan sosial pun dijadikan bahan untuk memperkaya diri sendiri atau orang lain. Perbuatan diatas dapat menimbulkan berbagai hal yaitu menghancurkan efektivitas potensial dari semua jenis program pemerintah, menghambat pembangunan, menimbulkan korban individual dan kelompok masyarakat. ${ }^{1}$ Oleh karena itu pemerintah harus melakukan pemberatasan yang sangat intensif terhadap kejahatan korupsi agar perkembangan di Indonesia bisa lebih maksimal dan tidak terhambat. Undang-Undang Nomor 31 Tahun 1999 juncto Undang-Undang Nomor 20 Tahun 2001 yang selanjutnya disebut sebagai Undang-

\footnotetext{
${ }^{1}$ Mansur Kertayasa, Korupsi dan Pembuktian Terbalik (Kencana 2017).[4].
} 
Undang tentang pemberantasan tindak pidana korupsi sebagai payung hukum untuk pemberatasan korupsi.

Dalam pemberatasan korupsi tidak cukup perangkat hukum saja melainkan juga membutuhkan peran aparat penegak hukum yang jujur, profesionalitas,dan berintergritas. Peran penyidik sangat penting guna mencari bukti terkait kerugian negara yang menjadi alat bukti awal dugaan tindak pidana korupsi dan menjadikan terang atau dapat diketahui tindak pidana yang terjadi. ${ }^{2}$ Peran Hakim ada peranan sangat penting dalam penegakan hukum karena hakim adalah penentu berguna atau tidaknya perangkat hukum yang dibuat oleh pemerintah. Hakim sebagai gerbang terakhir dalam penegakan hukum maka moralitas dan etika hakim harus dijunjung tinggi oleh setiap hakim khususnya hakim tindak pidana korupsi. Begitu pula dengan peran jaksa sebagai eksekutor dalam penengakan hukum.

Segala perbuatan pidana harus dibutkikan semua unsurnya beranjak dari asas legalitas yang ada Pasal 1 ayat 1 Kitab Undang-Undang Hukum Pindana yang selanjutnya disebut KUHP. Unsur terpenting dalam perbuatan pidana adalah unsur kesalahan begitu pula dengan perbuatan korupsi yang diatur dalamUndang-Undang tentang Pemberantasan Tindak Pidana Korupsi. Dalam tindak pidana korupsi dikenal juga unsur penyalahgunaan wewenang yang merupakan species dari genus unsur melawan hukum yang berarti secara implisit penyalahgunaan wewenang in haeren dengan melawan hukum. ${ }^{3}$ Penuntut umum dalam hal ini harus membuktikan perbuatan melawan hukum terdakwa dalam persidangan yang merupakan unsur utama dalam korupsi. Selain unsur melawan hukum ada pula unsur kerugian negara sebagaimana dimaksud dalam Pasal 2 dan Pasal 3 Undang-Undang tentang Pemberantasan Tindak Pidana Korupsi. Kerugian negara yang timbul akibat tindak pidana korupsi yang dimaksud dalam Undang-Undang tentang pemberantasan tindak pidana korupsi mengutamakan konsep pengembalian kerugian negara. ${ }^{4}$

\footnotetext{
${ }^{2}$ Adami Chazawi, Hukum Pidana Korupsi di Indonesia Raja Grafindo (Persada 2016).[346].

3 Nur Basuki Minarno, Penyalahgunaan Wewenang dalam Pengelolaan Keuangan Daerah, (Laksbang Mediatama 2008).[59].

${ }^{4}$ R. Bayu Ferdian, Mohd. Din, dan M.Gaussyah, 'State Losses in The Case Determination of The Crime of Corruption' (2018) 2 Syah kuala law journal.[2].
} 
Konsep tersebut diharapkan mampu mengembalikan kerugian negara akibat tindak pidana korupsi. Juga terdapat sanksi pidana tambahan pengembalian kerugian negara yang timbul. Berdasarkan putusan Mahkamah Konstitusi Nomor 25/PUUXIV/2016 menyatakan bahwa kata "dapat" dalam Pasal 2 dan Pasal 3 UndangUndang tentang pemberantasan tindak pidana korupsi tidak mempunyai kekuatan hukum mengikat. Oleh karena adanya putusan Mahkamah Konstitusi tersebut maka kerugian negara dalam Pasal 2 dan Pasal 3 Undang-Undang tentang pemberantasan tindak pidana korupsi tersebut menjadi delik materiil yang berarti harus ada kerugian negara yang timbul akibat unsur melawan hukumnya.

Mengenai soal perhitungan kerugian keuangan negara dalam Undang-Undang tentang Pemberantasan Tindak Pidana KorupsiKonsep perhitungan kerugian negara ini menimbulkan konflik yang dimana ada aturan yang kurang jelas menyebutkan bahwa lembaga yang berwenang menghitung kerugian negara. Terlalu banyak lembaga yang berwenang menghitung kerugian negara sehingga dapat menimbulkan konflik kewenangan. Dalam penjelasan Pasal 32 ayat (1) Undang-Undang tentang pemberantasan tindak pidana korupsi hanya menyebutkan "Yang dimaksud dengan secara nyata telah ada kerugian negara adalah kerugian negara yang sudah dapat dihitung jumlahnya berdasarkan hasil temuan instansi yang berwenang atau akuntan publik yang ditunjuk". Instansi yang berwenang yaitu Badan Pemerikasa Keuangan yang selanjutnya disebut (BPK), Badan Pengawasan Keuangan dan Pembangungan yang selanjutnya disebut (BPKP), Akuntan publik, dan Inspektorat. Dalam praktik tidak ada kepastian hasil perhitungan kerugian yang diterbikan oleh instansi yang melakukan perhitungan kerugian negara. Diikuti pula tidak adanya kepastian kompetensi lembaga yang melakukan kerugian negara tersebut jadi semua instansi dapat melakukan audit kerugian negara dalam kasus apapun tentu saja ini mempengaruhi kinerja hakim dalam mengadili suatu perkara.Apalagi dalam persidangan terdapat perbedaan hasil audit kerugian negara oleh instansiinstansi tersebut. Bahwa dalam praktik mengadili perkara hakim menilai kembali

\footnotetext{
${ }^{5}$ Undang-Undang Nomor 31 Tahun 1999 tentang Pemberantasan Tindak Pidana Korupsi.
} 
kerugian negara berdasarkan fakta persidangan untuk menentukan kerugian negara hasil tindak pidana korupsi dan dapat mengesampingkan perhitungan kerugian negara oleh masing-masing instansi yang berwenang. Bahwa hakim mempunyai wewenang yang telah diberikan oleh Undang-Undang Nomor 48 Tahun 2009 Tentang Kekuasaan Kehakiman untuk menemukan hukum, oleh karena itu apabila ada perbedaan hasil audit instansi maka hakim dapat menilai sendiri kerugian negara berdasarkan fakta persidangan.

Memang unsur yang lebih penting adalah unsur melawan hukumnya dan perhitungan kerugiannegarainimenjadi unsur kedua dalam mengadili perkara, tetapikonsep yang sudah di terapkan dalam Undang-Undang tentang pemberantasan Tindak Pidana Korupsi tentang pengembalian uang negara hasil korupsi ikhwalnya harus diterapkan dalam penegakan hukumnya. Dalam hal ini sesuai dengan konsep tujuan pemidanaan yaitu pidana bertujuan untuk menunjukan adanya kesebandingan penjatuhan pidana dengan beratnya kesalah anatau yang disebut proportionality. ${ }^{6}$ Sepandangan dengan teorinya John Kaplan dalam bukunya Criminal Justice yaitu teori penebusan dosa yakni penjahat membayar kembali utangnya bertujuan untuk memuaskan tuntutan keadilan, disini terpidana diharapkan terbebas dari beban moral akibat tindakan kejahatan yang dilakukan. ${ }^{7}$

\section{Kewenangan Hakim Menilai Sendiri Besarnya Kerugian Negara}

Perbuatan pidana adalah perbuatan yang dilarang oleh aturan hukum serta diberi ancaman sanksi yang berupa pidana tertentu, untuk barang siapa yang melanggar larangan tersebut. ${ }^{8}$ Akan tetapi perbuatan pidana tidak seluas itu, perbuatan pidana kiranya dapat disamakan dengan criminal act atau menjangkau akibat dari suatu kelakuan saja. Sedangkan dalam hukum pidana yang dimaksud ialah luas tidak hanya mengatur tentang akibat yang oleh peraturan dilarang saja, tetapi mengatur juga tentang kesalahan atau niat buruk seseorang yang dilakukan

\footnotetext{
${ }^{6}$ T.J. Gunawan, Konsep Pemidanaan Berbasis Nilai Kerugian Ekonomi (Kencana 2018).[76].

7 ibid.[77].

${ }^{8}$ Moeljatno, Asas-Asas Hukum Pidana Edisi Revisi (Rineka Cipta 2008).[59].
} 
oleh pelaku. Dengan kata lain tindak pidana atau isitilah Belanda disebut strafbaar feit. Simon berpendapat dalam buku Moeljatno bahwa strafbaar feit adalah kelakuan yang diancam dengan pidana. Sedangkan Van Hamel merumuskan dalam buku Moeljatno straf baar feit adalah kelakuan orang menselijke gedraging yang dirumuskan dalam wet atau hukum tertulis, yang bersifat melawan hukum, yang patut dipidana. ${ }^{9}$ Dengan didasari teori diatas maka dirumuskan menjadi tindak pidana karena tindak pidana menjangkau kelakuan dan akibat yang timbul. Unsur atau elemen tindak pidana menurut Didik Endro Purwoleksono terbagi menjadi lima macam yaitu kelakuan; hal ikhwal atau keadaan yang menyertai perbuatan; keadaan tambahan yang memberatkan; unsur melawan hukum objektif; dan unsur melawan hukum subjektif. ${ }^{10}$

Korupsi atau dengan bahasa latin corruptio atau corruptus dalam bahasa indonesia diartikan "busuk; palsu; suap". Secara harfiah istilah korupsi ialah segala perbuatan yang tidak baik, seperti yang dikatakan Andi Hamzah korupsi sebagai kebusukan, keburukan, kebejatan, ketidakjujuran, dapat disuap, tidak bermoral. ${ }^{11}$ Pemahaman tindak pidana korupsi berangkat dari pencurian dan penggelapan sebagaimana diatur dalam KUHP Pasal 362 juncto 372. Pencurian berdasarkan Pasal 362 KUHP adalah perbuatan secara melawan hukum mengambil barang milik orang lain dengan maksud memiliki. Adapun makna penggelapan berdasarkan Pasal 372 KUHP yaitu pencurian barang/hak yang dipercayakan atau berada dalam kekuasaan pelaku, yang ditekankan adanya penyalahgunaan wewenang pelaku terhadap barang yang dikuasai tetapi bukan miliknya. Dari penjelasan makna pencurian dan penggelapan maka tindak pidana korupsi yang sifatnya khusus lahir dari induknya yang umum yaitu KUHP. Selain itu tindak pidana korupsi juga menarik Pasal yang ada di KUHP antara lain Pasal 220, 231, 421, 422, 429, dan 430 sebagaimana diatur dalam Pasal 23 undang undang tentang pembertantasa tindak

\footnotetext{
9 ibid.[61].

${ }^{10}$ Didik Endro Purwoleksono, Hukum Pidana (Airlangga University Press 20140.[44-45].

${ }^{11}$ Andi Hamzah, Korupsi di Indonesia (Sinar Grafika 1991).[7].
} 
pidana korupsi. ${ }^{12}$ Dewasa ini tindak pidana korupsi mengalami perkembangan salah satunya aturan tentang subyek hukumnyat. Barang siapa hanya diatur dalam rumusan-rumusan Pasal Undang-Undang Nomor 1 Tahun 1946 tentang KUHP. Sedangkan dalam Undang-Undang tentang pemberantasan tindak pidana korupsi sudah mengganti "barang siapa" menjadi "setiap orang". Merumuskan subyek hukum menjadi luas yakni tidak hanya orang natuurlijk persoon tetapi mengakui badan hukum recht persoon sebagai subyek hukum. Berdirinya rumusan tindak pidana korupsi beranjak dari tindak pidana, sama hal nya dengan tindak pidana pada umumnya harus ada actus reus dan mens rea. Yang dimaksud Actus reus adalah perbuatan yang dilarang dalam peraturan perundang-undangan batasannya ialah asas legalitas. Adapun pengertian mens rea adalah pertanggung jawaban pidana dapat/ tidak dapat dipidananya pelaku batasannya ialah asas kesalahan. ${ }^{13}$ Pengertian tindak pidana korupsi dapat dijumpai dalam Undang-Undang tentang pemberantasan tindak pidana korupsi adalah suatu tindak pidana secara melawan hukum (formil maupun materiil) atau menyuap untuk memperkaya diri sendiri dan atau pihak lain (orang atau badan hukum), yang merugikan keuangan negara atau perekonomian negara. Lebih khusus korupsi adalah sebagaimana dirumuskan dalam Pasal 2 dan Pasal 3 UndangUndang tentang pemberantasan tindak pidana korupsi.

Dalam penjelasan Pasal 32 ayat 1 Undang-Undang tentang tipikor menyebutkan bahwa "Yang dimaksud dengan secara nyata telah ada kerugian negara adalah kerugian negara yang sudah dapat dihitung jumlahnya berdasarkan hasil temuan instansi yang berwenang atau akuntan publik yang ditunjuk". Instansi yang dimaksud ialah instansi yang diberi wewenang oleh peraturan perundang-undangan yang berlaku. Yaitu BPK diberikan kewenangan atribusi oleh Undang-Undang Dasar Negara Republik Indonesia Tahun 1945 dan UndangUndang Nomor 15 Tahun 2006 tentang Badan Pemeriksa Keuangan selanjutnya disebut BPK. Lalu ada BPKP yang diberikan kewenangan delegasi oleh presiden berdasarkan Peraturan Presiden Nomor192 Tahun 2014tentang Badan Pengawasan

\footnotetext{
${ }^{12}$ Adami Chazawi, Op.Cit.[18-19].

13 Didik Endro Purwoleksono, Op.Cit.[44].
} 
Keuangan Dan Pembangunan yang selanjutnya disebut BPKP. Adapun Jaksa atau Komisi Pemberantas Korupsi sebagai penutut umum berdasarkan putusan Mahkamah Konstitusi Nomor 31/PUU/X/2012 memberikan kewenangan pada penuntut umum dapat menghitung sendiri dengan bantuan instansi lain selain BPK dan BPKP. Dalam tulisan ini hanya mencantumkan tiga instansi yang berwenang karena berkaitan dengan isu hukum yang diangkat. Dengan adanya banyak instansi yang berwenang menimbulkan konflik kewenangan dalam praktik terdapat perbedaan hasil audit yang sama sahnya, tidak ada hierarki karena yang bertentangan hasil auditnya bukan norma hukum yang ada dalam perarturan perUndang-Undangnya. Dari sisi lain hakim dianggap tahu walaupun hukumnya tidak terlihat dipermukaan dan hakim tidak boleh menolak perkara berdasarkan Pasal 5 ayat (1) juncto Pasal 10 ayat (1) Undang-Undang Nomor 48 Tahun 2009 tentang kekuasaan kehakiman.

Adanya SEMA Nomor 4 Tahun 2016 memberikan pengaturan internal Mahkamah Agung berlaku untuk seluruh hakim dibawah Mahkamah Agung. SEMA kamar pidana Nomor 6 tersebut menyebutkan “.... dalam hal tertentu Hakim berdasarkan fakta persidangan dapat menilai adanya kerugian negara dan besarnya kerugian negara”. Hal ini membuktikan bahwa hakim berwenang menilai sendiri kerugian negara tidak terikat pada hasil audit instansi dalam persidangan. Hakim diperbolehkan untuk menilai sendiri berdasarkan fakta persidangan, walaupun nilai kerugian negara yang ditetapkan oleh hakim berbeda dengan hasil perhitungan instansi. SEMA ini merupakan implementasi peradilan yang merdeka dan berdaulat. Dasar hukum SEMA dapat dilihat bunyi Pasal 79 Undang-Undang Nomor 14 Tahun 1985 tentang mahkamah agung "mahkamah agung dapat mengatur lebih lanjut halhal yang diperlukan bagi kelancaran penyelenggaraan peradilan apabila terdapat hal-hal yang belum cukup diatur dalam Undang-Undang ini”. SEMA hanya bisa mengatur pengaturan dan melengkapi kekosongan hukum untuk memperlancar jalannya peradilan tidak boleh mengatur peraturan.

Dalam legislasi di Indonesia sering dijumpai kata kewenangan atau wewenang menurut kamus besar bahasa Indonesia kata wewenang disamakan dengan 
kewenangan. Berdasarkan Pasal 1 ayat 5 Undang-Undang Nomor 30 Tahun 2014 tentang administrasi pemerintahan menyebutkan bahwa "wewenang adalah hak yang dimiliki oleh badan dan/atau pejabat pemerintahan atau penyelenggara negara lainnya untuk mengambil keputusan dan/atau tindakan dalam penyelenggaraan pemerintahan". ${ }^{14}$ Kewenangan yang artinya adalah kekuasaan untuk bertindak, mengambil keputusan, dan hak untuk memerintahkan kepada pihak lain. ${ }^{15}$ Menurut Henc Van Marseveen dalam buku Phillipus Mandiri Hadjon wewenang minimal memuat tiga komponen yaitu adanya pengaruh, dasar hukum, konformitas hukum. Komponen pengaruh ialah adanya akibat hukum yang timbul mengatur tentang perilaku subyek hukum. Komponen dasar hukum bahwa wewenang itu selalu harus dapat ditunjuk dasar hukumnya dan komponen konformitas hukum mengandung makna adanya standard wewenang. ${ }^{16}$ Berangkat dari Pasal 1 angka 1 UndangUndang kekuasaan kehakiman bahwa:

"Kekuasaan Kehakiman adalah kekuasaan negara yang merdeka untuk menyelenggarakan peradilan guna menegakkan hukum dan keadilan berdasarkan Pancasila dan Undang-Undang Dasar Negara Republik Indonesia Tahun 1945, demi terselenggaranya Negara Hukum Republik Indonesia".

Apabila ditelaah norma Pasal tersebut maka dapat dibedakan antara wewenang dengan kewenangan berdasarkan subyek hukum yang membuatnya. Produk hukum lembaga yudikatif dikatergorikan sebagai kewenangan, sedangkan produk yang dikeluarkan oleh lembaga eksekutif itu disebut wewenang. Karena wewenang hanya untuk pejabat publik dan atau penyelenggara negara dalam lingkup pemerintahan. Jenis-jenis kewenagan dibedakan berdasarkan cara diperolehnya yaitu salah satunya cara atribusi ialah yang membuat keputusan bersumber langsung dari Undang-Undang. Kemudian dengan cara delegasi ialah yang membuat keputusan memperolehnya dari peraturan perundang-undangan.

\footnotetext{
${ }^{14}$ Undang-Undang Nomor 30 Tahun 2014 tentang administrasi pemerintahan (Lembaran Negara Tahun 2014 Nomor 292, Tambahan Lembaran Negara Nomor 5601), Ps. 1.

15 Kamal Hidjaz, Efektivitas Penyelenggaraan Kewenangan Dalam Sistem Pemerintahan Daerah Di Indonesia (Pustaka Refleksi 2010).[3].

16 Philipus Mandiri Hadjon, Tentang Wewenang (Yuridika 1997).[1].
} 
Kekuatan hukum SEMA tidak termasuk peraturan perundang-undangan sebagaimana dimaksud dalam Undang-Undang Nomor 11 Tahun 2012 tentang pembentukan perundang-undangan. Ketika menelaah ratio legis UndangUndang Nomor 11 Tahun 2012 tentang pembentukan perundang-undangan dapat ditarik definisi, bahwa peraturan perundang-undangan adalah peraturan tertulis yang memuat norma hukum yang mengikat secara umum dan dibentuk oleh lembaga atau pejabat negara yang berwenang. Bayu Dwi Anggono mengatakan SEMA hanya sebagai kebijakan beleidregel atau peraturan perundang-undangan semu pseudo wetgeving. ${ }^{17}$ Adanya SEMA Nomor 4 Tahun 2016 memberikan pengaturan internal Mahkamah Agung berlaku untuk seluruh hakim dibawah Mahkamah Agung. SEMA kamar pidana Nomor 6 tersebut menyebutkan “... dalam hal tertentu Hakim berdasarkan fakta persidangan dapat menilai adanya kerugian negara dan besarnya kerugian negara”. Ini membuktikan bahwa hakim dalam menilai kerugian negara tidak terikat pada hasil audit instansi dalam persidangan. Sejalan dengan ini tentunya mengingat hakim boleh melakukan penggalian hukum atau melakukan penemuan hukum berdasarkan penafsiran Pasal 10 Undang-Undang Nomor 48 Tahun 2009 tentang Kekuasaan Kehakiman hakim tidak boleh menolak perkara. Hakim diperbolehkan untuk menilai sendiri berdasarkan fakta persidangan, walaupun nilai kerugian negara yang ditetapkan oleh hakim berbeda dengan hasil perhitungan instansi. SEMA ini merupakan implementasi peradilan yang merdeka dan berdaulat. Dasar hukum SEMA dapat dilihat bunyi Pasal 79 Undang-Undang Nomor 14 Tahun 1985 tentang mahkamah agung "mahkamah agung dapat mengatur lebih lanjut hal-hal yang diperlukan bagi kelancaran penyelenggaraan peradilan apabila terdapat hal-hal yang belum cukup diatur dalam Undang-Undang ini”. SEMA hanya bisa mengatur pengaturan dan melengkapi kekosongan hukum untuk memperlancar jalannya peradilan tidak boleh mengatur peraturan.

\footnotetext{
${ }^{17}$ MYS, 'Surat Edaran Kerikil dalam Peraturan Perungang-undangan', (2015) < http://www. hukulonline.com>, dikunjungi pada tanggal 29 Oktober 2019.
} 


\section{Implementasi Surat Edaran Mahkamah Agung Nomor 4 Tahun 2016 Dalam Putusan Pengadilan Negeri Tindak Pidana Korupsi}

Dalam hal penjatuhan pidana oleh hakim terikat oleh peraturan perundangundangan yang berlaku atau yang disebut karena semua tindak pidana berdasarkan pada asas legalitas. ${ }^{18}$ Penjatuhan pidana tidak sama dengan penjatuhan hukuman karena penjatuhan hukuman lebih luas yakni menyangkut bidang perdata, administrasi, dan disiplin. Penjatuhan pidana berdasarkan padangan Muladi dan Barda Nawawi dikutip oleh Didik Endro pada hakikatnya merupakan suatu pengenaan penderitaan atau nestapa dan akibat lain yang merampas kebahagiaan. ${ }^{19}$ Berdasarkan Pasal 10 KUHP jenis pidana terbagi menjadi dua yaitu pidana pokok dan pidana tambahan. Pidana tambahan adalah pidana yang sifatnya fakultatif diserahkan oleh kewenangan hakim dan tidak dapat berdiri mandiri harus ada pidana pokok..$^{20}$ Besarnya nilai kerugian negara yang timbul sangat berpengaruh terhadap penjatuhan berat besarnya pindana pokok dan pidana tambahan. Dalam banyak perkara korupsi dibawah yang diputus oleh semua peradilan dibawah mahkamah agung mempertimbankan besarnya nilai kerugian negara, hal ini tentu berkaitan dengan Pasal 8 ayat (2) Undang-Undang 48 Tahun 2009 tentang kekuasaan kehakiman. Ketentuan tersebut harus menjadi acuan bagi para hakim dalam mempertimbangkan tentang pidana yang akan dijatuhkan kepada terdakwa yang terbukti melakukan tindak pidana korupsi. Disamping itu pidana tambahan juga diatur tersendiri oleh Undang-Undang tentang pemberantasan tindak pidana korupsi dalam Pasal 18. Khususnya dalam Pasal 18 ayat (1) huruf b berbunyi "pembayaran uang pengganti yang jumlahnya sebanyak-banyaknya sama dengan harta benda yang diperoleh dari tindak pidana korupsi”. Hal ini termasuk kategori penanggulangan korupsi yang dimana pada prinsipnya Pasal 18 ini mengutamakan pengembalian kerugian uang negara. Adanya kerugian negara atau keuangan negara membawa konsekuensi pada pelaku untuk mengganti kerugian negara

\footnotetext{
${ }^{18}$ Didik Endro Purwoleksono, Op.Cit.[31].

${ }^{19}$ ibid. [91].

${ }^{20}$ ibid.[97].
} 
schadevergoeding yaitu dengan cara dijatuhi pidana tambahan berdasarkan Pasal 18 ayat (1) huruf $b .{ }^{21}$ Penjatuhan pidana tambahan berupa uang pengganti tentu harus didasarkan pada jumlah nilai kerugian negara dan aliran dana yang dihasilkan dari tindak pindana korupsi berdasarkan fakta persidangan tentunya. Penentuan besarnya uang pengganti merupakan murni kewenangan hakim karena merupakan pidana tambahan.

Untuk mementukan nilai kerugian negara sangat tidak seimbang karena yang mempunyai kompetensi dibidang itu hanya penuntut umum untuk menghadirkan alat bukti berupa hasil audit dari instansi. Sedangkan terdakwa tidak mempunyai kompetensi dalam hal menghadirkan hasil audit dari instansi. Hal ini tentunya sangat mempengaruhi sisi keadilan dalam hukum yang dimana posisi terdakwa dengan penutut umum tidak sama equal tentunya bertentangan dengan asas equality before the law. Oleh karena itu dalam persidangan tentunya diperlukan adanya pembuktian. Pada proses pembuktian terjadi kolerasi dan interaksi mengenai apa yang dapat diterapkan oleh hakim dalam mememukan kebenaran materiil, begitu pula dengan hal dapatkah terdakwa dijatuhi pidana tambahan berupa uang pengganti. ${ }^{22}$ Penjatuhan pidana tambahan berupa uang pengganti tentunya tidak hanya didasarkan pada besarnya nilai kerugian negara dari hasil temuan instansi yang berwenang, tetapi dilihat pula apakah terdakwa ikut menikmati uang hasil tindak pidana korupsi tersebut. Untuk itu dalam menentukan besarnya kerugian negara ini dilakukan dengan pembebanan pembuktian sistem semi terbalik, yaitu pembuktian dengan dibebankan kepada penutut umum dan terdakwa. ${ }^{23}$ Penuntut umum mebuktikan dengan mengadirkan alat bukti hasil audit instansi, sedangkan terdakwa dapat membuktikan bahwa mungkin terdakwa telah menyadari adanya kerugian negara dan mengembalikan sebelum adanya persidangan. Peristiwa ini sering ditemui dalam pemeriksaan perkara dalam persidangan.

${ }^{21}$ Ridwan, Persinggungan Antar Bidang Hukum Dalam Perkara Korupsi (FH UII Press 2016).[86].

22 Mansur Kartayasa, Op.Cit.[193].

${ }^{23}$ Adam Chazawi, Hukum Pembuktian Tindak Pidana Korupsi (Media Nusa Creative 2018).[8]. 
Sebelum berlakunya SEMA Nomor 4 Tahun 2016 secara normatif hakim tidak bisa menilai kerugian negara berdasarkan fakta dipersidangan. Oleh karena itu hakim dalam perkara ini hanya memakai hasil penghitungan kerugian negara dari instansi yaitu BPKP dan BPK. Tentunya hal ini sangat menciderai asas keadilan seakan-akan hakim dalam mengadili perkara tidak memandang dari sisi obyektif melainkan sisi subyektif saja. Selain itu hakim dalam perkara ini tidak menunjukan kemerdekaan hakim dalam mengadili perkara hal ini ditunjukan dengan terikatnya hasil audit instansi terhadap putusan hakim. Pengertian menghitung menurut Kamus Besar Bahasa Indonesia ialah membilang untuk mengetahui berapa jumlahnya dengan cara menjumlah, mengurangi, dan sebagainya. Maka dari itu menghitung kerugian negara hanya dapat dilakukan oleh orang yang mempunyai ilmu akuntansi, Instansi yang berwenang BPK, BPKP, dan Inspektorat/Satuan Kerja Perangkat Daerah dalam SEMA Nomor 4 Tahun 2016 tentunya memiliki orang yang mempunyai ilmu akuntansi untuk menghitung kerugian negara. Beda halnya dengan menilai menurut Kamus Besar Bahasa Indonesia yaitu memperkirakan atau menentukan nilainya berdasarkan pengetahuannya. Kewenangan menilai dan menetapkan sendiri kerugian negara diberikan pada hakim dalam bunyi SEMA Nomor 4 Tahun 2016 berdasarkan yang diketahui oleh hakim dalam fakta persidangan. Kedua hal menilai dan menghitung ini tentunya sangat berbeda prosedur dalam cara menghasilkan nilai kerugian negara.

Penilaian oleh hakim tidak boleh semena-mena kehendak hakim tetapi harus memuat bukti yang cukup kuat untuk membuktikan bahwa memang nilai kerugian negara tersebut sesuai dengan fakta yang ada. Berdasarkan SEMA Nomor 4 Tahun 2016 hakim dapat menilai dan menetapkan kerugian negara didasari oleh fakta persidangan yaitu tentunya dengan alat bukti menurut Pasal 184 Kitab UndangUndang Hukum Acara Pidana Nomor 8 Tahun 1981. Dalam hal menilai dan menetapkan kerugian negara di persidangan tidak harus adanya perbedaan dua atau lebih Laporan Hasil Pemeriksaan Kerugian Keuangan Negara (LHPKKN) yang 
dibawa oleh Instansi yang berwenang. ${ }^{24}$ Apabila hanya ada satu saja Laporan Hasil Pemeriksaan atau satu penghitungan olek kejaksaan, hakim tetap bisa melakukan penilaian dan penetapan sendiri besarnya kerugian negara berdasarkan fakta persidangan. Hal ini tentunnya didasari oleh asas independensi hakim dan asas kemerdekaan pengadilan berdasarkan Undang-Undang Nomor 48 Tahun 2009 tentang Kekuasaan Kehakiman. Tentunya fakta persidangan yang dimaksud ialah keterangan yang didukung oleh alat bukti yang cukup kuat untuk membuktikan bahwa nilai kerugian negara yang timbul akibat tindakan terdakwa memang segitu nyatanya. Maka dari itu tolak ukur atau standarisasi hakim dalam menilai dan menetapkan besarnya kerugian negara melalui dua pendekatan yaitu pertama pemeriksaan fakta persidangan dan kedua pembalikan beban pembuktian oleh terdakwa. Dengan pendekatan yang kedua tentunya terdakwa dapat membuktikan besarnya kerugian negara yang mungkin tidak sesuai dengan hasil audit Instansi yang dibawa oleh penuntut umum. Adanya SEMA Nomor 4 Tahun 2016 menjadikan pengadilan yang merdeka, pengadilan mencitrakan keadilan dan kepastian hukum, hakim dapat melihat fakta dari sudut terdakwa dan penutut umum yang sama sama menunjukan terpenuhi atau tidaknya unsur-unsur tindak pidana korupsi.

Dalam ratio decidendi hakim tidak menjatuhkan pidana tambahan berupa uang pengganti karena kerugian negara sudah dikembalikan seluruhnya berdasarkan keterangan saksi. Selain itu penjatuhan pidana oleh hakim lebih ringan dari tuntutan jaksa karena mempertimbankan hal yang meringankan yaitu Terdakwa belum pernah dihukum, berlaku sopan, berterus terang dan menyesali perbuatannya dan Terdakwa telah mengembalikan kerugian keuangan Negara sejumlah Rp.240.387.100,00 (dua ratus empat puluh juta tiga ratus delapan puluh tujuh ribu seratus rupiah). Melihat ratio decidendi putusan hakim bahwa hakim menilai bahwa kerugian negara mencapai Rp.240.387.100,00 (dua ratus empat puluh juta tiga ratus delapan puluh tujuh ribu seratus rupiah) nilai ini lebih rendah dari hasil audit kerugian negara yang dihasilkan oleh BPKP. Hal ini sejalan dengan SEMA

${ }^{24}$ R. Bayu Ferdian, Mohd. Din, dan M.Gaussyah, Op.Cit.[329] 
Nomor 4 Tahun 2016 huruf A angka 6 yakni dalam hal tertentu hakim dapat menilai kerugian negara sendiri. Disamping itu hakim berpendapat BPKP berwenang melakukan pemeriksaan dan audit walaupun tidak ada temuan BPK terlebih dahulu. BPKP melakukan audit dengan mendahului audit oleh BPK karena didalamnya secara materiil dapat mengandung tindak pidana. Oleh karena itu Badan Pengawas Keuangan dan Pembangunan (BPKP)/Inspektorat/Satuan Kerja Perangkat Daerah secara delegatif tetap berwenang melakukan pemeriksaan dan audit pengelolaan keuangan Negara, dan menyimpulkan hasil audit tersebut berupa opini auditor ada atau tidaknya penyimpangan keuangan negara. Opini atau pendapat auditor tersebut sesuai dengan ketentuan Pasal 184 (Undang-Undang Nomor 8 Tahun 1981 tentang kitab Undang-Undang hukum acara pidana) KUHAP merupakan keterangan Ahli sesuai Pasal 186 KUHAP juncto Pasal 179 KUHAP juncto Pasal 197 ayat (1) huruf h KUHAP. Keterangan ahli tersebut menjadi alat bukti menjadi pertimbangan hakim apakah dapat dijadikan dasar terpenuhinya unsur kerugian negara. Dalam hal tertentu secara delegatif berdasarkan Pasal 7 juncto Pasal 8 Undang-Undang Nomor 12 Tahun 2011 tentang pembentukan peraturan perundang-undangan Pasal 79 Undang-Undang Nomor 3 Tahun 2009 perubahan kedua juncto Undang-Undang Nomor 5 Tahun 2004 perubahan pertama atas Undang-Undang Nomor 14 Tahun 1985 juncto SEMA 4 Tahun 2016. Hakim menjatuhkan pidana pada terdakwa dengan alat bukti keterangan saksi dan keterangan ahli yang telah sesuai dengan pasal 183 Kitab Undang-Undang Hukum Acara Pidana.

Setelah berlakunya SEMA Nomor 4 Tahun 2016 hakim tidak lagi terikat oleh hasil audit instansi, melainkan hakim dapat menilai sendiri kerugian negara berdasarkan fakta dipersidangan. Fakta persidangan diperoleh dari keterangan saksi dan tentunya didukung sekurang-kurangnya dua alat bukti berdasarkan Pasal 183 juncto 184 ayat (1) Undang-Undang Nomor 8 Tahun 1981 tentang Kitab Hukum Acara Pidana. Dengan ini membuktikan bahwa nilai keadilan dijunjung tinggi serta independensi hakim dalam mengadili perkara dengan melihat sisi obyektif maupun subyektif. 


\section{Kesimpulan}

Bahwa kedudukan terdakwa terkait pembuktian kerugian negara tidak mempunyai kompetensi untuk menghadirkan bukti kerugian negara dari hasil audit instansi BPK, BPKP, dan Inspektorat ini membuat posisi terdakwa dengan penuntu $t$ umum tidak adil. Oleh karena itu hakim pada pengadilan negeri tindak pidana korupsi mempunyai kewenangan diperoleh dari Pasal 6 surat edaran mahkamah agung Nomor 4 Tahun 2016 sesuai dengan Pasal 79 Undang-Undang Nomor 14 Tahun 1985 tentang mahkamah agung bahwa surat edaran mahkamah agung mempunyai dasar hukum yang diatur oleh Undang-Undang dengan menilai sendiri kerugian negara berdasarkan fakta persidangan yaitu keterangan ahli dan keterangan saksi untuk menyeimbangkan posisi terdakwa terhadap penuntut umum agar mencapai keadilan.

Bahwa nilai kerugian negara berpengaruh penting terhadap penjatuhan pidana khususnya pidana tambahan berupa uang pengganti, dalam pembahasan kasus dalam bab sebelumnya menunjukan apabila kewenangan hakim menilai kerugian negara sendiri berdasarkan fakta persidangan dirasa perlu dan penting untuk mencapai keadilan. Tidak akan tercapai keadilan apabila hakim hanya berpegangan terhadap hasil audit instansi yang berwenang saja. Dalam keterangan perundang-undangan tidak disebutkan dengan jelas nama lembaga apa yang berwenang dalam mendeclare nilai kerugian negara, sehingga terjadinya ketidakpastian disaat menentukan lembaga sebagai auditor kerugian negara BPK/BPKP. Dampak standar ganda terhadap proses serta hasil dari audit nilai kerugian negara karena memang kedua lembaga tersebut memiliki metode serta prinsip yang berbeda. Undang-Undang tentang Pemberantasan Korupsi menjadi celah terjadinya peluang permainan dalam penanganan tindak pidana korupsi, oleh karena BPK dan BPKP yang keduanya memiliki kewenangan untuk menetapkan nilai kerugian negara, maka dalam praktik Jaksa khususnya dapat memilih satu diantara keduanya. 


\section{Daftar Bacaan}

\section{Buku}

Mansur Kartayasa, Korupsi dan Pembuktian Terbalik (Kencana 2017).

Adami Chazawi, Hukum Pidana Korupsi di Indonesia (Raja Grafindo Persada 2016).

Gunawan T.J., Konsep Pemidanaan Berbasis Nilai Kerugian Ekonomi (Kencana 2018).

Peter Mahmud Marzuki, Penelitian Hukum (Kencana Prenada Media 2005).

Abdulkadir Muhammad, Hukum dan Penelitian Hukum (Citra Aditya Bakti 2004).

Nur Basuki Minarno, Penyalahgunaan Wewenang dalam Pengelolaan Keuangan Daerah (Laksbang Mediatama 2008).

Philipus Mandiri Hadjon, Tentang Wewenang (Yuridika 1997).

Sudikno Mertokusumo, Penemuan Hukum Sebuah Pengantar (Liberty 1996).

Didik Endro Purwoleksono, Hukum Pidana (Airlangga University Press 2014).

Andi Hamzah, Korupsi di Indonesia (Sinar Grafika 1991).

Kamal Hidjaz, Efektivitas Penyelenggaraan Kewenangan Dalam Sistem Pemerintahan Daerah di Indonesia (Pustaka Refleksi 2010).

\section{Jurnal}

Ferdian, R. Bayu, Mohd. Din, dan M.Gaussyah, 'State Losses in The Case Determination of The Crime of Corruption' (2018) Syah kuala law journal.

Abdurahman, Ali, dan Rahayu Prastiningsih, 'Peraturan Yang Dibentuk Oleh Lembaga Negara Selain Legislatif Dan Eksekutif’ (2011) PSKN-FH Unpad

\section{Laman}

Mahkamah Agung Republik Indonesia (Ringkasan Eksekutif Laporan Tahunan 2018), <http://kepaniteraan.mahkamahagung.go.id > dikunjungi pada tanggal 1 April 2019.

MYS, (Surat Edaran Kerikil dalam Peraturan Perungang-undangan, 2015) <http:// www.hukulonline.com> dikunjungi pada tanggal 29 Oktober 2019. 